Jerzy Marek

marekimarek@wp.pl

\title{
Jeden świat, dwa style. Wokół korespondencji Jarosława Iwaszkiewicza i Kazimierza Orłosia
}

\author{
One World, Two Styles: Reflections around the Correspondence of Jarosław \\ Iwaszkiewicz and Kazimierz Orłoś
}

\begin{abstract}
The article offers a commentary on the correspondence of Jarosław Iwaszkiewicz and Kazimierz Orłoś during 1958-1974. The author reconstructs the evolution of the relationship of the two writers - from the initial courtesy of a debutant towards the master to the cooling of their relations due to the peculiarity of the literary life in the "Polish People's Republic." The article presents two attitudes towards the reality of that time. The unequivocal political choices of Kazimierz Orłoś, so much different from the servilistic strategy adopted by Jarosław Iwaszkiewicz, were the reason that, despite the social affinities and the mutual respect for their work, the two writers had to part ways.
\end{abstract}

Keywords: Jarosław Iwaszkiewicz, Kazimierz Orłoś, correspondence, literary life, "Polish People's Republic"

Streszczenie: Artykuł jest komentarzem do korespondencji Jarosława Iwaszkiewicza i Kazimierza Orłosia, która trwała od 1958 do 1974 roku. Autor odtwarza ewolucję relacji obu pisarzy - od początkowej kurtuazji debiutanta wobec mistrza do wynikającego ze specyfiki życia literackiego w PRL-u ochłodzenia stosunków. W artykule ukazano dwie postawy wobec peerelowskiej rzeczywistości. Jednoznaczne wybory polityczne i etyczne Kazimierza Orłosia, tak odmienne od ugodowej strategii obranej przez Jarosława Iwaszkiewicza, spowodowały, że mimo towarzyskich koligacji oraz wzajemnego szacunku dla twórczości drogi obu pisarzy musiały się rozejść.

Słowa kluczowe: Jarosław Iwaszkiewicz, Kazimierz Orłoś, korespondencja, życie literackie, PRL

Pierwsze swoje opowiadania dwudziestotrzyletni Kazimierz Orłoś zaniósł osobiście Jarosławowi Iwaszkiewiczowi do redakcji „Twórczości” na ulicy Wiejskiej 16 w Warszawie ${ }^{1}$. Stało się to zapewne w marcu bądź kwietniu 1958 roku, bowiem 28 kwietnia Iwaszkiewicz napisał: „Drogi Panie Kazimierzu! Niech Pan koniecznie zajdzie do redakcji w krótkim czasie, koło południa. Mamy Panu dużo do powiedzenia” (1), co - jak komentuje Beata Zybała - związane było

${ }^{1}$ K. Orłoś, Dzieje dwóch rodzin, Mackiewiczów z Litwy i Ortosiów z Ukrainy, Kraków 2015, s. 9. 
z przekazaniem wiadomości, „że opowiadanie Dziewczyna z tódki zostanie wydrukowane we wrześniowym numerze »Twórczości« z 1958 roku”2.

Osoba młodego pisarza od pierwszego spotkania połączyła się w pamięci Iwaszkiewicza z dziecięcymi latami spędzonymi na Ukrainie, bowiem jego nazwisko przypomniało mu towarzyszkę z bardzo dawnych czasów:

Kiedy się przedstawiłem, zapytał od razu, kim była dla mnie Bogumiła Orłosiowa. A to była matka mego ojca - moja babka po mieczu, Zwolińska z domu, żona mego dziadka, Tadeusza. Iwaszkiewicz pamiętał ją - z majątku naszych wspólnych krewnych, Iwaszkiewiczów z Oratowa na Ukrainie

- wspomina Kazimierz Orłoś w Dziejach dwóch rodzin ${ }^{3}$. Pokrewieństwo to było dosyć skomplikowane:

A jeszcze te związki z Iwaszkiewiczem, ponieważ Oratów na Podolu należał do jego krewnego - Ferdynanda Iwaszkiewicza, żonatego z Sabiną ze Sławińskich, czyli ciotką mojej babki Bogumiły (...). Ojciec mojej babki, Karol [Zwoliński - J.M.] (...) [o]żenił się z Marią z domu Sławińską. (...) Iwaszkiewiczowie spokrewnili się ze Sławińskimi w drugiej połowie XIX wieku, kiedy dwie siostry Sławińskie wyszły za mąż. Sabina za Ferdynanda Iwaszkiewicza właściciela Oratowa, a Maria za prawnika Karola Zwolińskiego. Maria była moją rodzoną babką ze strony matki, Sabina - babką cioteczną .

Bogumiła Orłosiowa w zapiskach Iwaszkiewicza pojawia się kilkakrotnie, zawsze w takiej samej, jak będziemy mieli okazję zobaczyć, sytuacji. Najwcześniej w Dziennikach, w zapisie z 9 października 1961 roku, poczynionym w Sandomierzu:

Wracałem, stanąłem na Świętopawelskiej. Drzewa jeszcze zielone, jeden klon żółty, słońce świeciło przez liście. (...) W starym domku za drzewami ktoś grał nieustannie na rozstrojonym fortepianie Rewe ta stohne Dnipr szyjrokij. Zrobiło mi się niesamowicie. Przypomniałem sobie, jak śpiewaliśmy to w lesie, w Oratowie, u pani Sabiny Iwaszkiewiczowej - siostry, Anielka, Jaś Iwaszkiewicz, Bogusia Orłoś (...).

2 J. Iwaszkiewicz, K. Orłoś, Korespondencja z lat 1958-1974, podała do druku i oprac. B. Zybała, „Twórczość” 2017 , nr 2, s. 75-85. Wszystkie cytaty podaję za tą edycją, zaznaczając w nawiasie numer listu.

${ }^{3}$ K. Orłoś, Dzieje dwóch rodzin..., dz. cyt., s. 9.

${ }^{4}$ Tamże, s. 10, 36, 112-113. Uściślijmy, że Maria była prababką ze strony ojca, natomiast Sabina - prababką stryjeczną Kazimierza Orłosia. Autor dziękuje za sprostowanie Kazimierzowi Orłosiowi. 
Było to chyba w 1898 czy 1899 roku. I raptem mi się tak wszystko, wszystko przewinęło. Niesłychany moment. I ten leciutki szelest żółknących liści. Cudownies

Ten obecny w zapisku proustowski ton wywołały: stara pieśń ukraińska, jesienne światło i szelest liści, ale być może jakąś ewokacyjną rolę odegrał tu także list Kazimierza Orłosia, napisany 3 października tego samego roku (6). Nie przez poruszone w nim wątki, choć autor pisze tu nieco o urokach Krutyni, bardziej chyba ze względu na osobę, a zwłaszcza nazwisko pisarza.

Do tego czasu korespondencja obu twórców, wspomniany już pierwszy list Iwaszkiewicza oraz cztery listy z 1961 roku $(2,3,4,5)$, dotyczyła spraw literackich i w pewnej mierze osobistych, związanych z pracą Kazimierza Orłosia, choć trzeba przyznać, że w niektórych obserwacjach autora Końca zabawy widać już charakterystyczne dla jego prozy uwrażliwienie na szczegół, a także zdolność do opisania ponurej, peerelowskiej rzeczywistości w kilku przejmujących zdaniach:

Lato w Turoszowie jest bardzo uciązliwe - rozgrzane powietrze przesycone zapachem hałd, przejazd każdego samochodu to chmura kurzu, bardzo brak drzew, wody. Ratuję się wycieczkami na rowerze w okolice Zgorzelca - właściwie naokoło same lasy (5).

Orłoś, pracujący wtedy w Biurze Prawnym Kombinatu turoszowskiego (2) i mieszkający w dość uciążliwych warunkach w hotelu robotniczym w Zgorzelcu, jest wdzięczny redaktorowi za wsparcie, posyła kolejne opowiadania przeznaczone dla „Twórczości”, dziękuje za pochlebne opinie na temat swych utworów, wreszcie ofiarowuje Iwaszkiewiczowi swą debiutancką książkę Między brzegami $^{6}(2,4,5)$. Iwaszkiewicz pisze w odpowiedzi jeden list (3), w którym między innymi chwali opowiadania Orłosia („mimo że, jak wszystko u Pana, są takie okrutne”) i cieszy się z wydania przez niego książki. Relacja jest tu jednoznaczna - młody adept, a później debiutant, korzysta z życzliwości dojrzałego twórcy i ustosunkowanego luminarza życia literackiego. Oczywiście, autor Dziewczyny z tódki nie jest tu wyjątkiem. Przed nim z takiej pomocy korzystało wielu twórców, że wspomnimy choćby najbardziej oczywiste przypadki Pawła Hertza czy Czesława Miłosza ${ }^{7}$ Iwaszkiewicz zawsze interesował się młodą literaturą̧, był też jednym z najwybitniejszych polskich redaktorów XX wieku.

5 J. Iwaszkiewicz, Dzienniki 1956-1963, oprac. A. i R. Papiescy, R. Romaniuk, wstęp A. Gronczewski, Warszawa 2010, s. 481. W tytule pieśni błąd, prawdopodobnie redakcji.

${ }^{6}$ K. Orłoś, Między brzegami, Warszawa 1961.

7 Zob. P. Hertz, A. i J. Iwaszkiewiczowie, Korespondencja, t. 1-2, oprac., układ A. i R. Papiescy, Warszawa 2015; C. Miłosz, J. Iwaszkiewicz, Portret podwójny, wybór tekstów, red., układ B. Toruńczyk, oprac., przypisy R. Papieski, Warszawa 2011.

8 Ślady tych zainteresowań rozsiane są w felietonach z cyklu Rozmowy o książkach, publikowanych na łamach „Życia Warszawy” w latach 1954-1979. 
Po liście napisanym przez Orłosia 3 października w Krutyni (6) ton Iwaszkiewicza się zmienia. Odnosimy wrażenie, że uruchomił on jakiś ciąg wspomnień, że właśnie za jego sprawą w pamięci pisarza „wszystko [się - J.M.] przewinęło", bowiem 13 października, a więc kilka dni po odnotowaniu w Dziennikach tego - jak go nazwał - „niesłychanego momentu”, pisze bardzo czuły, osobisty list (7), w dużym stopniu powtarzający zapis dziennikowy:

\section{Kochany Kaziu -}

Byłem ostatnio w Sandomierzu. Szedłem wąwozem, nade mną stały żółkniejące drzewa, w liściach lekko szeleściło, a poza tym cisza i spokój. Ze starego domku obok wąwozu dolatywały dźwięki rozstrojonego fortepianu. Słuchałem uważnie i długo. Ktoś grał ukraińską pieśń Rewe ta stohne Dnipr szyrokij.

Przypomniało mi się, że śpiewaliśmy tę pieśń, jadąc bryczką lasem późnym wieczorem u pani Sabiny Iwaszkiewiczowej w Oratowie. Gdzieś w 1898 czy 99 roku. Były moje siostry, Jaś Iwaszkiewicz, i kto jeszcze? Kto jeszcze? Ależ oczywiście, Bogusia Orłoś. Taka była ładna i młoda. A ja taki malutki. No i wzruszyłem się. (...) Zajdź do redakcji, bardzo się tam Ciebie lubi. (...)

Widać wyraźnie, że babka Orłosia odegrała jakąś istotną, choć niejasną rolę w życiu cztero- bądź pięcioletniego Iwaszkiewicza. Wróci on jeszcze do tej postaci pod koniec życia, w 1977 roku, podczas pisania, redagowania i korekty Podróży do Polski?. W rozdziale Kraków po raz ostatni spotkamy znaną nam już scenę. Wspomnienie z Oratowa pojawia się tym razem za sprawą opowieści o pierwszej podróży do tego majątku:

Wizyta u Pietraszkiewiczowej! To była najmłodsza z trzech sióstr Sławińskich, siostra Janiny Szatrowskiej, przyjaciółki mamy, i Lońci Chmielewskiej (...). Te trzy siostrzenice pani Sabiny Iwaszkiewiczowej, (...) to te siostrzenice pani Sabiny, z którymi razem jeździło się do lasu i w powrotnej drodze śpiewało „Rewe taj stohne...”. Były tam jeszcze Amelka Załuska, Kostunia Witwicka, Bogusia Orłoś... ${ }^{10}$

Wróćmy do cytowanego wyżej listu z 13 października 1961 roku. Familiarny zwrot do Orłosia jest ewenementem $\mathrm{w}$ tej korespondencji, zresztą w późniejszym, grudniowym, jak można sądzić, dopisku do tego samego listu Iwaszkiewicz nieco się wycofuje i pisze „Kochany Panie Kaziu” (7). Wyjątkowy na tle całej omawianej tu korespondencji jest też jego język, tak bliski prozie autora Ogrodów. Za przykład niech posłuży pisane u schyłku życia opowiadanie Sérénité. Dostrzec w nim możemy podobną metaforykę i słownictwo

9 P. Hertz, A. i J. Iwaszkiewiczowie, dz. cyt., t. 2, s. 161.

${ }^{10}$ J. Iwaszkiewicz, Podróże do Polski, Poznań [2009], s. 71-74. W tytule pieśni błąd, prawdopodobnie redakcji. 
oraz typową dla prozy Iwaszkiewicza wrażliwość na przeszłość; na kolory, smaki, zapachy i melodie dzieciństwa:

(...) pamiętam (...) ten powrót o świcie wzdłuż krat Luksemburskiego Ogrodu. Ogród był jeszcze zamknięty, ale był świt czerwcowy i pachniało rosą, i jakieś ptaszki śpiewały. Nie mówiliśmy wiele, nie mówiliśmy o przeszłości, tylko pani raz powiedziała:

„Pachnie rosą w ogrodzie, jak u nas na Ukrainie”.

Teraz mi się wydaje, że to był moment wielkiego szczęścia. (...)

Zapach rosy był czymś, co nas łączyło $(\ldots)^{11}$.

Po tym niezwykłym liście korespondencja zamiera na kilka lat, do 1964 roku. Kolejny jej blok obejmuje lata 1964-1965 i składa się z dwóch zachowanych i dwóch zaginionych listów Orłosia (przed 8, przed 912, 10,12) oraz $\mathrm{z}$ trzech listów Iwaszkiewicza $(8,9,11)^{13}$. Jest to czas komponowania drugiego tomu opowiadań pisarza, zatytułowanego Koniec zabawy ${ }^{14}$.

Korespondencja powraca do rzeczowego, choć pełnego życzliwości tonu. Iwaszkiewicz cieszy się, że Orłosiowi udało się pokonać trudności wydawnicze, pociesza go i obsypuje pochwałami, troszczy się o jego talent, a także ma nadzieję na „istotną” (,jak mówił Witkacy”) rozmowę (8). Martwi się, że Orłoś w Solinie nic nie pisze, namawia go do powrotu do Warszawy (9) czy też kwituje odbiór opowiadań dla „Twórczości” (11). Orłoś z kolei pisze o kłopotach z wydaniem w Państwowym Instytucie Wydawniczym drugiego tomu opowiadań (list zaginiony, przed 8), dziękuje za otuchę, przedstawia nowe utwory (10) czy wreszcie przesyła Iwaszkiewiczowi swoją książkę, opublikowaną ostatecznie przez wydawnictwo Czytelnik (12).

Chyba nie odczuwa potrzeby bliższej, bardziej intymnej znajomości. W drugim zaginionym liście (przed 9), jak wynika z odpowiedzi Iwaszkiewicza, daje do zrozumienia, że nie jest skłonny do zwierzeń. Jego korespondent pisze: „Szkoda, że Pan się powściąga, "aby nie mówić o sobie«, a przecież to zawsze ciekawe. Chciałbym wiedzieć o Panu zawsze jak najwięcej” (9).

Trzeba przyznać, że Orłoś wciąż bardzo sobie ceni życzliwość Iwaszkiewicza. W liście z 20 listopada 1965 roku pisze z Soliny:

11 Tenże, Sérénité [w:] tegoż, Opowiadania, t. 6, Warszawa 1980, s. 299.

${ }^{12}$ Istnienia tego zaginionego listu autorka opracowania nie odnotowuje w przypisie.

${ }^{13} \mathrm{Z}$ tego też okresu pochodzi krótka (jedyna?) wzmianka Jarosława Iwaszkiewicza o twórczości Kazimierza Orłosia, zob. J. Iwaszkiewicz, Wspótcześni, „Życie Warszawy” 1965, nr 177. Felieton z cyklu Rozmowy o książkach, przedrukowany w wydaniach książkowych z 1968 i 1983 roku, dotyczy antologii 31 wspótczesnych opowiadań, wyb., oprac. A. Bukowska, Warszawa 1965.

${ }^{14}$ K. Orłoś, Koniec zabawy, Warszawa 1965. 
Bardzo Panu dziękuję za druk moich opowiadań w majowym numerze „Twórczości”. Dziękuję także za ostatni list. Każdy list od Pana jest dla mnie wydarzeniem czasem, kiedy jest mi ciężko, czytam je po raz drugi, żeby nabrać otuchy (12).

Od bardziej intymnych wyznań jednak stroni i kto wie, czy nie jest to powodem kolejnego zawieszenia korespondencji, tym razem do roku 1969. Być może Jarosław Iwaszkiewicz poczuł się zawiedziony w swoich oczekiwaniach; wiemy z rozmaitych świadectw, jak bardzo lubił towarzystwo młodych ludzi (zwłaszcza artystów) i jak bardzo go oni inspirowali. Przy czym nie chodziło mu wyłącznie o fascynację erotyczną, raczej o oparty na takim fundamencie głęboki kontakt duchowy. Najbardziej bezpośrednio wyraził to chyba w liście do żony, Anny Iwaszkiewiczowej, pisanym z Genewy 26 września 1931 roku:

Nie wróciłbym do wielkiego włoskiego malarstwa, gdyby nie entuzjazm Józika [Rajnfelda ] - nie przejąłbym się tym, gdybym nie żył z nim razem intymnie. Oczywiście nie było między nami stosunku cielesnego, ale ten stosunek duchowy, w którym zrozumiałem jego i sam w sobie odnalazłem tak wiele, nie mógłby „zaistnieć”, gdyby nie podkład erotyczny. Tak samo nigdy bym nie zrozumiał tak głęboko duszy Niemiec (...), gdybym nie poznał Karla [Schefolda] i nie odbył tego spaceru jesiennego na piechotę z Heidelbergu do katedry w Spirze. Z kobietą nawet najmądrzejszą nie przeżyje się właśnie tego sięgnięcia w istotę pewnych rzeczy ${ }^{15}$.

Korespondencję odnawia Orłoś. Nastąpiło to 24 lutego 1969 roku (13) i znów związane było z publikacją książki - Ciemnych drzew, trzeciego tomu opowiadań ${ }^{16}$. W tym bloku, obejmującym lata 1969-1972, znajdują się cztery listy Orłosia $(13,14,15,17)$ i jeden list Iwaszkiewicza (16). Oprócz zwyczajowych wyrazów szacunku i pamięci pojawia się tu nowy, obecny w każdym liście autora Samotności mężczyzny wątek - nieśmiałości, która nie pozwala mu na częstsze kontakty z prezesem ZLP: „Przepraszam, że odzywam się tak rzadko i nie zachodzę do Redakcji - to już tylko wina mojej nieśmiałości” (13); „Moje milczenie jest, jak już wspominałem, tylko i wyłącznie oznaką nieśmiałości” (14); „Przepraszam za swój brak śmiałości skontaktowania się z Panem bezpośrednio telefonicznie i osobistego doręczenia książki” (15). Iwaszkiewicz chwali opowiadania Orłosia, pisząc: „Książkę już przedtem czytałem zawsze z tym samym zachwytem i zasmuceniem”; „Zawsze pragniemy czytania pańskich smutnych, przejrzystych a przymglonych opowiastek".

15 A. i J. Iwaszkiewiczowie, Listy 1927-1931, oprac. M. Bojanowska, E. Cieślak, przypisy muzyczne A. Matracka-Kościelny, Warszawa 2012, s. 525. Co ciekawe, wydaje się, że Anna Iwaszkiewiczowa jest podobnego zdania. W swoich Dziennikach 28 sierpnia 1925 roku zapisała: „Jednak Jarosław ma rację: pewien pierwiastek erotyczny jest zawsze tym, co czyni przyjaźń takim słodkim uczuciem (...)”. Zob. A. Iwaszkiewiczowa, Dzienniki i wspomnienia, do druku podała M. Iwaszkiewicz, oprac. przypisy P. Kądziela, Warszawa 2012, s. 112.

${ }^{16}$ K. Orłoś, Ciemne drzewa, Warszawa 1970. 
Niezobowiązująco zaprasza go także do odwiedzenia Stawiska (16). Orłoś odpisał dopiero po z górą dwóch latach, 20 grudnia 1972 roku, znów tłumacząc się nieśmiałością (17), jednak wydaje się, że to raczej wybory polityczne i etyczne powodują, że drogi obu pisarzy powoli zaczynają się rozchodzić.

W pierwszych miesiącach 1973 roku Kazimierz Orłoś podjął decyzję o opublikowaniu pod własnym nazwiskiem powieści Cudowna melina w Instytucie Literackim w Paryżu ${ }^{17}$. Wypada przypomnieć, z jak wielkim ryzykiem i odwagą się to wiązało - autor mógł być pewien różnorakich represji ze strony władzy i prawdopodobnie także ostracyzmu nastawionej konformistycznie części środowiska literackiego. Przejęty Jerzy Giedroyc 5 lutego 1973 roku pisze do Czesława Miłosza:

Młody pisarz z kraju, który mnie zresztą parokrotnie odwiedzał, zdeponował u mnie rok temu rękopis swej książki z tym, że jeśli zażądają od niego zmian, to chce drukować u mnie pod swym nazwiskiem. Właśnie dostałem od niego prośbę, by drukować, i to spiesznie. Ponieważ to dla chłopca, który jest młody i nienależący do żadnej sitwy, jest duże ryzyko, skomunikowałem się z nim raz jeszcze, wskazując niebezpieczeństwa i radząc się zastanowić. Odpowiedział z naciskiem, że nie zmienia decyzji ${ }^{18}$.

27 lutego tego roku w liście do Juliusza Mieroszewskiego powtarza: „chłopiec bardzo odważny. Mimo że go przestrzegałem przed konsekwencjami, uparł się, by drukować" ${ }^{19}$. Leszek Kołakowski jest pewien represji, jakie spadną na Orłosia, choć ma nadzieję, ,że go do więzienia nie wsadzą"20. Więzienie pisarza ominęło, jednak konsekwencje były bardzo poważne. Po licznych przesłuchaniach pisarza zwolniono z pracy w Polskim Radiu i w tygodniku „Literatura" oraz skazano na całkowity zakaz druku' ${ }^{21}$. W Czarnej księdze cenzury $P R L$ pojawił się następujący zapis: „Nie należy zezwalać na publikację żadnych utworów Kazimierza Orłosia. Ewentualne publikacje dotyczące tego autora

${ }_{17}$ Krok ten rozważał prawdopodobnie już w roku 1972. 15 marca tego roku Jerzy Giedroyc pisał do Juliusza Mieroszewskiego: „Możliwe, że dostanę dużą powieść polityczną pisarza krajowego o znanym nazwisku, ale to jeszcze na wodzie pisane". Niewykluczone, że mowa tu o książce Orłosia. Zob. J. Giedroyc, J. Mieroszewski, Listy 1957-1975, cz. 3, oprac., wstęp, przypisy R. Habielski, Warszawa 2016, s. 197.

18 J. Giedroyc, C. Miłosz, Listy 1973-2000, oprac. M. Kornat, Warszawa 2012, s. 9.

19 J. Giedroyc, J. Mieroszewski, Listy..., dz. cyt., cz. 3, s. 248. Dodajmy, że Orłoś był jednym z pierwszych autorów krajowych, który zdecydował się na opublikowanie książki w Instytucie Literackim pod własnym nazwiskiem.

${ }^{20}$ J. Giedroyc, L. Kołakowski, Listy 1957-2000, wstęp P. Kłoczowski, oprac., przypisy H. Citko, Warszawa 2016, s. 102.

${ }^{21}$ Więcej na ten temat zob. K. Orłoś, Historia „Cudownej meliny”, Paryż 1987. 
winny być każdorazowo uzgadniane z kierownictwem GUKPPiW [Głównego Urzędu Kontroli Prasy, Publikacji i Widowisk - J.M.]”22.

$\mathrm{Z}$ tego czasu pochodzą ostatnie listy Iwaszkiewicza i Orłosia, w tym bardzo ważny list autora Cudownej meliny, w którym obok podziękowań za życzliwość i wsparcie w trudnej sytuacji znajduje się sformułowane wprost credo pisarskie:

Interesują mnie sprawy społeczne, chciałbym - a może tak tylko potrafię - pisać o trudnych sprawach życia w Polsce, których przecież niemało. Mam wrażenie, że przy tak donośnie brzmiącym chórze samozadowolenia, apologetyki i afirmacji - głosy tego typu, jaki reprezentuję, są potrzebne. Dlatego rosnąca ingerencja cenzury, to stałe zwężanie marginesu krytyki, ta niechęć do mówienia o rzeczach przykrych - są szczególnie niepokojące. Nie chcę i nie potrafię przestawić się na stary nurt moich opowiadań, trochę sielskich, czy ograniczać się do spraw z zakresu psychologii lub moralności (18).

Widzimy, że narodził się pisarz świadomy swych celów, ale przede wszystkim przekonany, iż proza realistyczna w kraju takim jak PRL zawsze będzie natrafiać na kłopoty z cenzurą i władzą. Od tej chwili aż do odzyskania przez Polskę suwerenności Kazimierz Orłoś swoje utwory wydawał wyłącznie w oficynach podziemnych i emigracyjnych. Coraz bardziej też angażował się w działalność opozycyjną, zwłaszcza związaną z życiem literackim, a to z pewnością nie sprzyjało korespondencji z prezesem Związku Literatów Polskich. Dość zdawkowa odpowiedź Iwaszkiewicza (19) zawiera co prawda wyznanie wiary w talent Orłosia, ale także nieco paternalistyczne, podszyte biblijną aluzją napomnienie: „Oczywiście we Francji drukować nie trzeba, bo tam tacy sami, tylko w lustrze, więc nierealni”. Na tym - nie licząc dwóch kart świątecznych wysłanych w 1974 i 1975 roku do Stawiska $(20,21)$ - listowny dialog obu pisarzy się kończy.

Nie wydaje się, żeby Jarosławem Iwaszkiewiczem kierowały tu jakieś względy oportunistyczne. Korespondował przecież z wieloma twórcami emigracyjnymi: z Czesławem Miłoszem, Konstantym Jeleńskim, Witoldem Gombrowiczem czy Mieczysławem Grydzewskim ${ }^{23}$. Bardziej prawdopodobne jest, że mogło to mieć związek z wydarzeniami mającymi miejsce podczas XIX Zjazdu ZLP, który odbył się w lutym 1975 roku w Poznaniu. Kazimierz Orłoś napisał z tej okazji list będący protestem przeciwko cenzurze, odczytany

${ }^{22}$ Czarna księga cenzury PRL, t. 1-2, Londyn 1977. Cyt. za: K. Orłoś, Historia „Cudownej meliny", dz. cyt., s. 65.

${ }^{23}$ Zob. C. Miłosz, J. Iwaszkiewicz, dz. cyt.; J. Iwaszkiewicz, T. Jeleńska, K.A. Jeleński, Korespondencja, oprac., przypisy R. Romaniuk, Warszawa 2008; Listy Witolda Gombrowicza do Jarostawa Iwaszkiewicza, „Twórczość” 1969, nr 12; M. Grydzewski, J. Iwaszkiewicz, Listy 19221967, oprac. M. Bojanowska, Warszawa 1997. 
na prośbę pisarza przez Marka Nowakowskiego. Tłumaczył w nim między innymi powody wydania Cudownej meliny w Paryżu:

Chciałem w ten sposób zaprotestować przeciwko cenzurze. Chciałem zwrócić uwagę na jaskrawo występującą niekonsekwencję: z jednej strony dyskusja w prasie (...) o moim pokoleniu, które, zdaniem krytyków, unikało książek poruszających tematykę współczesną, z drugiej strony zakaz pisania na ten temat wszystkiego, bez przemilczeń i ukrywania prawdy. (...)

Skoro [książkę - J.M.] wydałem w Paryżu (...) - uznano ten fakt za dowód wrogości. Zareagowano zakazem druku jakichkolwiek moich tekstów. Jak zły uczeń zostałem postawiony do kąta. (...) moje opowiadanie złożone w „Twórczości” [mowa o Drzewie Pana Jezusa - J.M.] nie mogło się ukazać24 . (...)

Nie mogę zgodzić się z argumentami ludzi, którzy uważają, że wydając książkę we Francji postąpiłem nieodpowiedzialnie, a następstwa były do przewidzenia. (...) Uważam, że nienormalna jest raczej sytuacja, gdy nie można wydać krytycznej książki [w kraju - J.M.], a mówienie o wolności słowa i potrzebie ograniczenia cenzury uznawane jest za lekkomyślność lub nieodpowiedzialność. Czy nie takim postawom zawdzięczamy swobodny rozwój wielostopniowego systemu cenzury?25

Z listu wyłania się portret autora bezkompromisowego, pisarza stojącego na gruncie prawdy i odpowiedzialności za swoje decyzje i zaniechania. Czy jego słowa były wymierzone bezpośrednio w Iwaszkiewicza? Trudno jednoznacznie wyrokować, ale wydaje się, że prezes ZLP mógł je tak odebrać. Z relacji Kazimierza Orłosia wynika, że jeszcze podczas zjazdu Iwaszkiewicz tłumaczył, iż dwukrotnie próbował drukować w „Twórczości” Drzewo Pana Jezusa, jednak za każdym razem sprzeciw zgłaszała cenzura ${ }^{26}$. Niemniej cała ta sytuacja musiała go głęboko dotknąć, bowiem w swoich Dziennikach, w zapisie z 24 lutego 1975 roku, skomentował pobyt w Poznaniu bardzo krótko, jakby wypierając przykry dla niego incydent z pamięci:

Dzisiaj powrót samochodem z Poznania. Z tych trzech dni nie zostają w pamięci odgłosy meskinerii i nienawiści, drobnostkowości ludzkiej i zabiegania o własny interes, nie obraz miasta ani tych ludzi, tylko obraz tej jazdy ${ }^{27}$.

Nazwisko Orłosia tu nie pada, ale z wielu relacji wiemy, że sprawa publikowania w wydawnictwach emigracyjnych wywołała najbardziej burzliwa

${ }^{24}$ Opowiadanie ukazało się ostatecznie w pierwszym numerze drugoobiegowego „Zapisu”, zob. „Zapis 1”, styczeń 1977, Londyn 1977, s. 131-144.

${ }^{25}$ Cyt. za: K. Orłoś, Historia „Cudownej meliny”, dz. cyt., s. 78-79.

26 Tamże, s. 80.

27 J. Iwaszkiewicz, Dzienniki 1964-1980, oprac., przypisy A. i R. Papiescy, R. Romaniuk, wstęp A. Gronczewski, Warszawa 2011, s. 432. 
dyskusję podczas zjazdu. Rozgorzała ona - jak można sądzić na podstawie zapisu z Dziennika Jana Józefa Szczepańskiego ${ }^{28}$ - właśnie po odczytaniu listu przez Marka Nowakowskiego. Marta Fik w Kulturze polskiej po Jatcie odnotowała, że Kazimierz Koźniewski i Zbigniew Załuski wyrazili dezaprobatę dla pisarzy publikujących w paryskiej „Kulturze”, natomiast Tomasz Burek, Przemysław Bystrzycki, Anna Kamieńska i Jan Józef Szczepański ostro krytykowali „brak wolności słowa i deptanie praw twórcy w PRL”29. Wszystko to mogło być przyczyną zerwania korespondencji pomiędzy pisarzami.

Wiele już - choć nie zawsze sprawiedliwie - napisano o postawie Jarosława Iwaszkiewicza po drugiej wojnie światowej ${ }^{30}$. Mamy świadomość, że nie był on - eufemistycznie mówiąc - zwolennikiem emigracji, krytycznie też odnosił się do wszelkich opozycyjnych wystąpień pisarzy w Polsce, począwszy co najmniej od Listu 34. „Trzydziestu czterech poważnych ludzi wymierzyło mi głęboki cios, taki, z którego się nie podniosę, może nawet w historii”, zanotował w Dziennikach 11 kwietnia 1964 roku $^{31}$. Jeśli chodzi o interesujące nas tu lata siedemdziesiąte, można przywołać późniejsze notatki z Dzienników. Powstanie Komitetu Obrony Robotników, którego założycielami byli między innymi Stanisław Barańczak i Jerzy Andrzejewski, Iwaszkiewicz kwituje zdaniem: „zaczęły się te bzdury z KOR-em”, oraz przypuszcza niewybredny atak na autora Popiotu i diamentu ${ }^{32}$ (notatka z 25 grudnia 1976 roku), natomiast o „Zapisie”, pierwszym drugoobiegowym czasopiśmie literackim, redagowanym zresztą między innymi przez Orłosia, ma do powiedzenia tyle, że jest on „idiotyczny” (notatka z 26 stycznia 1980 roku) ${ }^{33}$.

Korespondencja, o której była tu mowa, skupia jak w soczewce problemy, z jakimi zmagali się pisarze w czasach PRL-u. Bywają w dziejach Polski takie chwile, że wybory polityczne mają decydujący wpływ na kształt relacji międzyludzkich. Mimo wspólnych korzeni i wzajemnego szacunku dla swojej twórczości drogi osobowości tak różnych, o tak odmiennych postawach, musiały się prędzej czy później rozejść. Nigdy już do siebie nie napisali.

${ }^{28}$ J.J. Szczepański, Dziennik, t. 4: 1973-1980, Kraków 2015, s. 175.

29 Zob. M. Fik, Kultura polska po Jatcie. Kronika lat 1944-1981, Londyn 1989, s. 558. Notka ta przywołana jest też w Dziennikach 1964-1980 Iwaszkiewicza, w przypisie na s. 433.

${ }^{30}$ Zob. między innymi G. Herling-Grudziński, K.A. Jeleński, Dwugtos o Iwaszkiewiczu [w:] G. Herling-Grudziński, Wyjścia z milczenia, Warszawa 1998 oraz w: K.A. Jeleński, Zbiegi okoliczności, Paryż 1982; S. Kisielewski, Wedtug alfabetu, Warszawa 1988; M. Radziwon, Iwaszkiewicz. Pisarz po katastrofie, Warszawa 2010; R. Romaniuk, Inne życie. Biografia Jarostawa Iwaszkiewicza, t. 2, Warszawa 2017.

${ }^{31}$ J. Iwaszkiewicz, Dzienniki 1964-1980, dz. cyt., s. 39. Iwaszkiewicz szeroko komentował tę inicjatywę w Dziennikach, zob. zwłaszcza s. 38-59.

32 Tamże, s. 491. Iwaszkiewicz zapisał między innymi: „Tak jakby polski robotnik (wspaniały i rozumiejący) nie umiał dać sobie rady i potrzebował opieki starego durnia i pijanicy Andrzejewskiego i jeszcze podobnych facetów”. W następnym zdaniu nazwał Andrzejewskiego „zapijaczonym pederastą, który niczego z sytuacji robotników w Polsce nie rozumie.

33 Tamże, s. 611. 


\section{Bibliografia}

Czarna księga cenzury PRL, t. 1-2, Londyn 1977.

Fik M., Kultura polska po Jatcie. Kronika lat 1944-1981, Londyn 1989.

Giedroyc J., Kołakowski L., Listy 1957-2000, wstęp P. Kłoczowski, oprac., przypisy H. Citko, Warszawa 2016.

Giedroyc J., Mieroszewski J., Listy 1957-1975, cz. 3, oprac., wstęp, przypisy R. Habielski, Warszawa 2016.

Giedroyc J., Miłosz C., Listy 1973-2000, oprac. M. Kornat, Warszawa 2012.

Grydzewski M., Iwaszkiewicz J., Listy 1922-1967, oprac. M. Bojanowska, Warszawa 1997.

Herling-Grudziński G., Wyjścia z milczenia, Warszawa 1998.

Hertz P., Iwaszkiewiczowie A. i J., Korespondencja, t. 1-2, oprac., układ A. i R. Papiescy, Warszawa 2015.

Iwaszkiewicz J., Dzienniki 1956-1963, oprac., przypisy A. i R. Papiescy, R. Romaniuk, wstęp A. Gronczewski, Warszawa 2010.

Iwaszkiewicz J., Dzienniki 1964-1980, oprac., przypisy A. i R. Papiescy, R. Romaniuk, wstęp A. Gronczewski, Warszawa 2011.

Iwaszkiewicz J., Podróże do Polski, Poznań [2009].

Iwaszkiewicz J., Rozmowy o książach, Warszawa 1983.

Iwaszkiewicz J., Sérénité [w:] tegoż, Opowiadania, t. 6, Warszawa 1980.

Iwaszkiewicz J., Wspótcześni, „Życie Warszawy” 1965, nr 177.

Iwaszkiewicz J., Jeleńska T., Jeleński K.A., Korespondencja, oprac., przypisy R. Romaniuk, Warszawa 2008.

Iwaszkiewicz J., Orłoś K., Korespondencja z lat 1958-1974, podała do druku i oprac. B. Zybała, „Twórczość” 2017, nr 2.

Iwaszkiewiczowa A., Dzienniki i wspomnienia, do druku podała M. Iwaszkiewicz, oprac., przypisy, indeks P. Kądziela, Warszawa 2012.

Iwaszkiewiczowie A. i J., Listy 1927-1931, oprac. M. Bojanowska, E. Cieślak, przypisy muzyczne A. Matracka-Kościelny, Warszawa 2012.

Jeleński K.A., Zbiegi okoliczności, Paryż 1982.

Kisielewski S., Wedtug alfabetu, Warszawa 1988.

Listy Witolda Gombrowicza do Jarostawa Iwaszkiewicza, „Twórczość” 1969, nr 12.

Miłosz C., Iwaszkiewicz J., Portret podwójny, wybór tekstów, red., układ B. Toruńczyk, oprac., przypisy R. Papieski, Warszawa 2011.

Orłoś K., Ciemne drzewa, Warszawa 1970.

Orłoś K., Dzieje dwóch rodzin, Mackiewiczów z Lituy i Ortosiów z Ukrainy, Kraków 2015.

Orłoś K., Historia „Cudownej meliny”, Paryż 1987.

Orłoś K., Koniec zabawy, Warszawa 1965.

Orłoś K., Między brzegami, Warszawa 1961.

Radziwon M., Iwaszkiewicz. Pisarz po katastrofie, Warszawa 2010.

Romaniuk R., Inne życie. Biografia Jarostawa Iwaszkiewicza, t. 2, Warszawa 2017.

Szczepański J.J., Dziennik, t. 4: 1973-1980, Kraków 2015. 